\title{
The contradiction between production, marketing and consumption of organic food: supply of organic products in the city of Barcelona
}

\author{
X. A. Armesto-López \& M. B. Gómez-Martín \\ Department of Physical Geography and Regional Geographical Analysis, \\ University of Barcelona, Spain
}

\begin{abstract}
This paper aims to reflect on the possible contradictions that occur between the marketing of organic food that can be found in the usual places and the principles underlying the production philosophy of these. For this purpose is a sample of products that include the categories of the most consumed by the general public (fruit, vegetables, dairy products, etc.) and identify their geographical origins. The place in which the study is conducted is the city of Barcelona (Catalonia, Spain) and it will visit a selection of shops dedicated solely to the sale of organic products and a choice of department stores that have a section differentiating organic food. The results show how the number of organic products found on the shelves of the stores produced in remote geographical site marketing is considerable. Therefore, it calls into question one of the pillars that underpin the ecological philosophy: the proximity of the producer. Hence, that can corroborate the "conventionalization" of organic farming, something that already alerted some authors several years ago. The potential role of organic products with regard to sustainability, the attitude of the authorities and consumer access to these products in the near future will be important issues in the social debate.
\end{abstract}

Keywords: organic food, products’ geographical origin, Barcelona. 


\section{Introduction}

This work is aimed primarily to reflect the origin of organic food consumed in Spain. It shows the situation in the city of Barcelona. This city can be illustrated with respect to the main consumption patterns since the Spanish population is mainly concentrated in urban areas with over 10,000 inhabitants (76\%). In this sense, Barcelona is the second largest city of the Spanish side with 1615448 inhabitants [1]. Meanwhile, consumption of organic food in Spain, takes place in the whole territory, but achieved greater prominence in the Northeast and in large cities [2]. Thus, Barcelona would fit perfectly within these two coordinates (great city and northeastern end of the peninsula).

The city of Barcelona is the capital of Catalonia, and as has been said, the second Spanish city in population, only behind Madrid. Furthermore, Barcelona should be considered an important economic social, cultural and consumer hub in the context of the Western Mediterranean. From this city it's articulated an important part not only in Catalonia but also throughout the Spanish Mediterranean coast. We need to relate this reflection with the fact that from the perspective of organic production, according to the Ministry of Agriculture, Food and Environment [3]. Catalonia is one of the Spanish regions with higher declared area, 92435 ha. We have to consider this area as a pioneer in the introduction of this type of production and, at present days is a leader in the number of importers (35) and processors (606) of organic food materials [3].

Organic production and marketing of their products are considered as strategic objectives for the Spanish government and the European Union (EU). Among the reasons that support the initiatives in this direction to strengthen the sector should be noted with respect to the protection and improvement of the prestigious image of high quality products produced in Spain [4]. It is in this sense that we have to consider this work as it aims to map the geographical origin of organic products. The growing importance of the positive assessment regarding the proximity of the product has led some government try to create distinctive provenance attesting that the product near food. The most recent example in this regard is the creation on January 8, 2003 by the Catalan government of a creating proximity's food products sale tag [5].

The characteristics of the Spanish organic food industry should be emphasized. First, Spain has established itself in recent years as the EU country that devotes more area to organic farming over 1845000 ha, followed by Italy and Germany, the fifth worldwide. Despite presenting the figure as high, the proportion of land set to organic farming is only $1.5 \%$ of total agricultural area, still far from European countries with long experience in these practices and greater environmental commitment [6]. The average for the EU-27 is 5.1\% [7]. Therefore, it follows the other aspect to be considered when defining the Spanish organic agriculture: $80 \%$ of production is exported [4].

Moreover, the organic sector in Spain begins to have a significant industrial processing structure. There were in 20112729 processors of organic food [3]. However, the trading structure is still limited [2] and there is a minimum domestic market for organic products. This market was a total of between $€ 905$ 
million [7] and $€ 920$ million [3], with an average expense of about $20 €$ per person per year (reduced to $15 €$ in the case of Catalonia), below European countries like Switzerland, Denmark, Austria, Germany or France. This figure is equivalent to only $1 \%$ of domestic expenditure on food and beverages in Spain (in Denmark reached 7.2\% and in Germany 3.5\%). An example of this attitude spread in northern Europe is the fact that only $9 \%$ of the Danes do not ever buy organic products [8]. These differences may be based on not only the different consumer awareness, also plays an important role in the fact that countries with higher ratios organic products have a greater role on the shelves of large chain selling food. Thus, the presence of organic products in this type of establishments has the advantage of exposing the green product to a large number of consumers. This fact expands their knowledge and, therefore, the demand and the purchase option in all sales channels [4]. This is an argument that says Hjelmar [8] too focused on his job in Denmark. This is a question that can also be identified as a priority for the promotion of local products such as point Weatherell et al. [9] in a paper not limited to organic food.

This paper identifies the origins of the main types of organic foods that are purchased in Spain retail. The supply of these products is varied and depends on the type of establishment. Thus, larger establishments have fresh vegetable and animal, refrigerated foods, processed foods and in some cases non-food products. Meanwhile, smaller establishments do not usually offer fresh animal products, except in some cases, certain dairy products.

The issue of greater consumer awareness and ethics and their relationship to the territory of origin appears also referred to a study dedicated to organic olive oil [10]. These authors suggest an interesting field of study that is the consumer interpretation by the coexistence of designations of origin and organic agriculture in the same product. There will be attentive to the evolution of the information of food products, since the excess of information for a product may generate misunderstandings and confuse consumers [11]. In the results of the study referred above sponsored by the [2] appears a statement that it has served to frame the initial research question. Thus, the statement that organic consumer "prefers to consume products closer to their environment (...)" made us wondering where did organic products consumed in the city of Barcelona come from? To identify its origin we copy the behaviour that it presupposes to organic consumer report "consumers are well informed, they read the labels of the products they buy (...)”. Therefore, an important part of the field work was based on reading the product labels to find their geographical origin. In the case of fresh produce were asked makers, owners and managers of selected shops.

By contrast, in another opinion poll, this time confined to Catalonia [12], 59\% of respondents erroneously thought that "organic foods are always in season and sold near where they are grown.” Precisely, the initial premise on which organic consumers seem to mind the origin in Spain is discussed if we consider the results of the work of Gracia and de Magistris [13] in which they conclude that the origin of the product does not have statistics relevance in the purchase decision process in southern Italy. So to try to contribute something more to clarify these spatial relationships, this work was performed. The key question to answer is: it 
is possible for a standard client identify the geographical origin of organic products?

\section{Research method}

The establishment of the work's universe was complex. It took as its starting point the information available in one of the Internet search portals known in Spain. So, by filtering option they were identified 25 shops in the municipality of Barcelona. But this result presented two problems: a) it was not represented the typology of hypermarkets that every year captures a higher percentage of green consumers, b) they were not represented all scalar fields we had decided to study at city. To address these shortcomings was decided to expand the search criteria on the web and make visual surveys in some major surfaces present in the city. Therefore, we selected 10 different shops, each located in a different district of the municipality. As a result, the geographical coverage was complete as Barcelona is divided into 10 districts. Thus, we attempted to explore in all socioeconomic contexts of the city trying so, capture the possible differences in the supply of products.

In each of the selected establishments are filled in a form that sought to identify the origin of a total of 100 products, grouped into eleven categories (fruit, vegetables, legumes, dried fruits, soft drinks, dairy products, cereals and derivatives, prepared vegetables, meat products, alcoholic beverages and various foods). In this paper we have chosen those that are considered the three most important categories: fruit, vegetables and dairy products. Why this decision is made because the vegetables and fruits are the organic products most consumed along and along with dairy products serve to begin in organic food consumption [2].

According to the Barometer of perception and consumption of organic food [12] is in a retailer where the majority (54.1\%) of the products are purchased. In hypermarkets, supermarkets and department stores are made for $36.7 \%$ of purchases. Agree on the same line market research on organic product in Spain sponsored by the former Ministry of Environment, Rural and Marine Affairs [4] shows the distribution of organic products by sales channels: hypermarkets and supermarkets (20\%), shops (75\%), other (5\%).

Given all these considerations, the final fieldwork was conducted in six stores specializing in the sale of organic products, two supermarkets specializing in such products and two large surfaces have a line of organic products but mainly selling conventional products. Specialty stores in which data were collected were also attending dimension criteria. Thus, they went to stores small (less than $140 \mathrm{~m}^{2}$ ) and medium size (from 140 to $400 \mathrm{~m}^{2}$ ). In the case of supermarkets, one of them was unique, while the other was part of a chain specializing in this type of products. Regarding the two major surfaces, both is European capital (French and Spanish), one of these is more specialized in food, but it also has other products, while the other is multi, no food being its main product group. 
Within this methodology, finally, it should be noted that the field work was carried out during the Christmas season. The reason for choosing these dates was to introduce the effect of unusual food consumption at other times of the year, but typical of these festivities, to see if this fact had often reaching significance in the organic market, especially in some meats and some fruits and vegetables.

\section{Results}

According to the report commissioned by the Government of Catalonia for the views of consumers of organic food [12] 50.1\% of buyers preferred not buy organic but produced in Catalonia. Thus, the origin of products is gaining importance in the process of purchase decision. This trend in the local product preferentially positioned as consumer choice and appears in a clear way in places like the UK at the beginning of this century [9]. As announced in the previous section, it was tried to check the geographic origins of 100 products, although in this work we have selected three of the eleven presented groups: fruits, vegetables and dairy products.

\subsection{The geographical origin of fruits}

After tabulating the results obtained from the field, the general pattern is the main source of this type of product is the Catalan territory (Fig. 1). The map that follows shows as the fruits are mostly Catalan origin when it comes to seasonal produce. The regions of the $\mathrm{S}$ and $\mathrm{W}$ are the main sourcing of these products to the Catalan capital. Certainly, it can say that they are mostly local products.

In this food category were detected 10 products. There was a higher prevalence of themselves this season (apple, pear, orange, kiwi), along with some fruit like bananas, which have a constant crop throughout the year and reaches markets from Canary Islands to mainland Spain. Besides the Canaries also identified other Spanish regions that provided an important fruit amount to shops in Barcelona. Thus, some Andalusian provinces were the source of some tropical fruits (i.e. mango) or together with region of Valencia citrus production.

It must be highlighted the territories of the Ebro river Valley (La Rioja and Navarra) as a source of production, especially apples and pears. Exotic fruits, which are assumed to have a higher consumption during the holidays, are those that have a more distant origin. Brazil and Costa Rica in Latin America and the Ivory Coast in Africa are the countries from which they import these products in the organic market. Thereby, the organic market assumes conventional market traits. Consequently, they have a high environmental impact caused by the transport. However, there are still no season products that are impossible to find in any of the organic shops in Barcelona (i.e. strawberries, cherries, peaches, apricots or melons). Special mention of the two European countries also provides organic products on the shelves of Barcelona. The French case is related to the strength of the organic market in the south. The distance from one of these market centers with the Catalan border is only $50 \mathrm{~km}$ and therefore, some Northern Catalonia's distributors come on weekly to buy products such as 
kiwifruit. Products from Italy were identified primarily in a large store in which they conducted the field work. So everything suggests that this time supply policy of the Company makes that the product has an Italian origin.

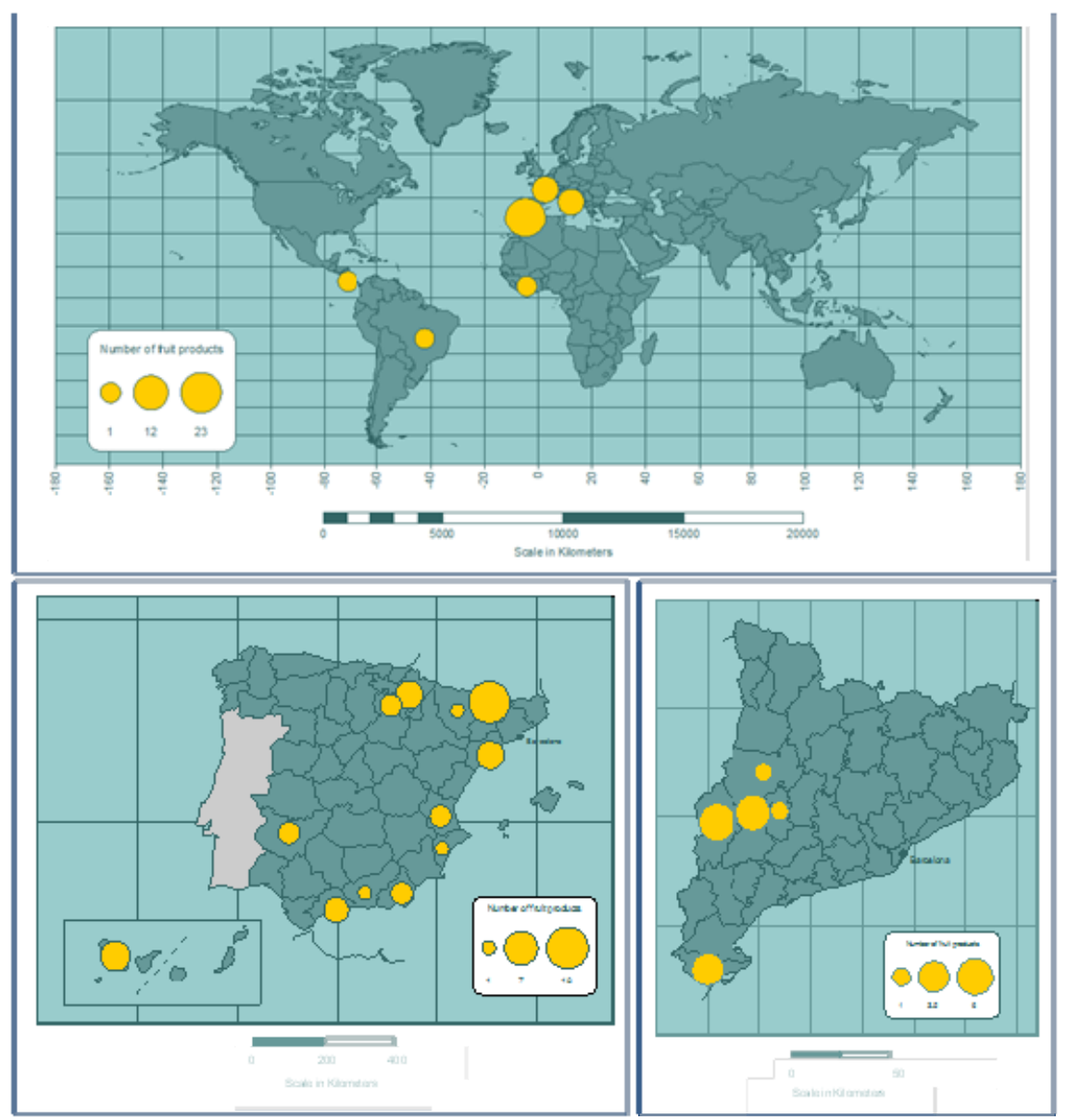

Figure 1: Geographical origin of organic fruit products.

\subsection{The origin of the vegetables}

In contrast with fruits all vegetables were found, at least in one establishment, a total of 16 vegetables, which had been arisen in the design of the database. In this case, there is a broader spatial representation of the origin of such products; firstly the cultured product is remarkable in the inland region of Catalonia (Fig. 2). 

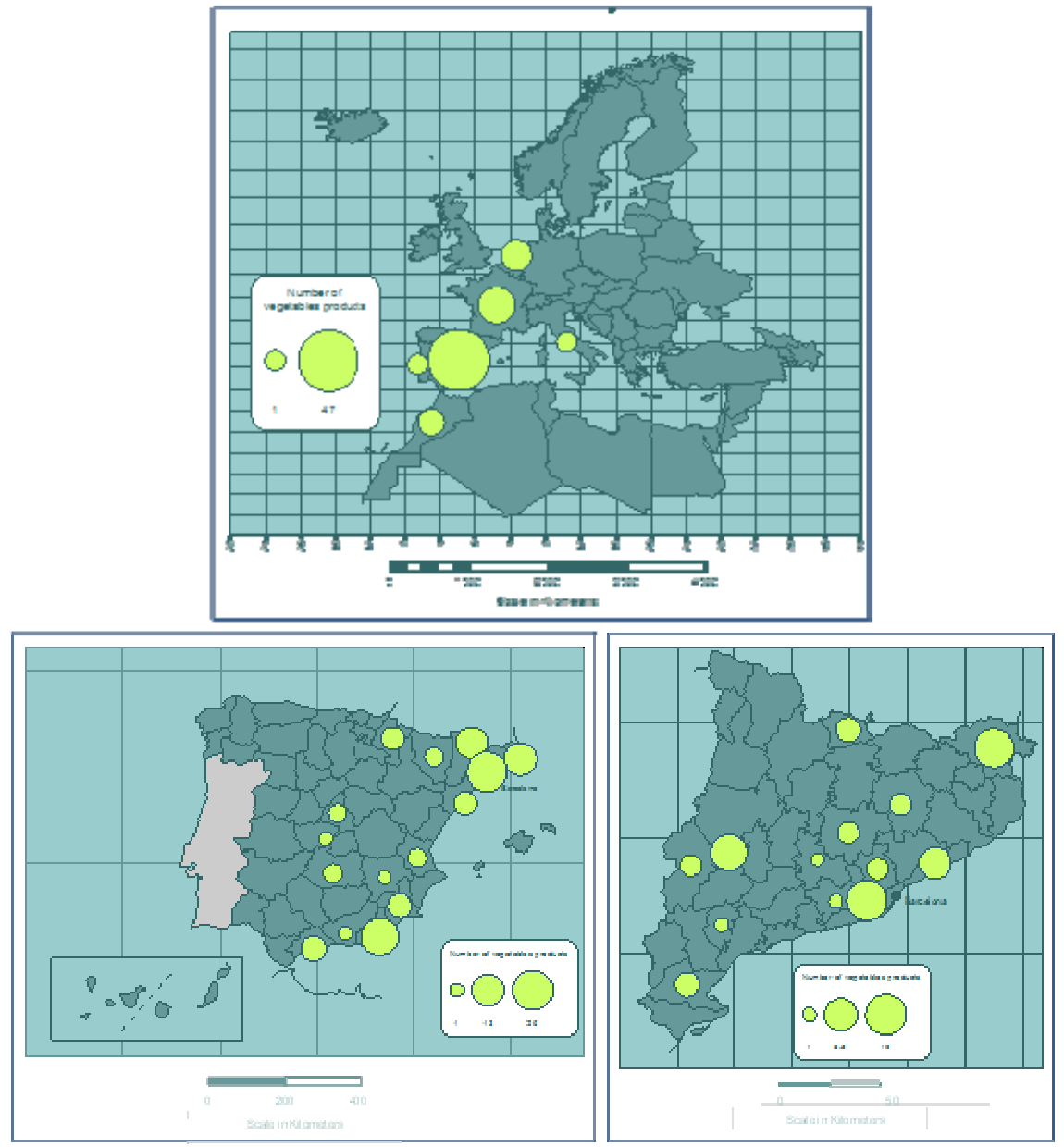

Figure 2: $\quad$ Geographical origin of organic vegetable products.

We can identify three main origins from which these products are supplied to businesses in the city of Barcelona:

a) The metropolitan territory of the self conurbation of Barcelona, where the Baix Llobregat to the SW of the city and the Maresme NE of the city have traditionally been the market garden of Barcelona;

b) The regions of the west (Pla d'Urgell and Segrià), one of the main agriculture areas and where is located one of the biggest producers and distributors businesses of organic farming;

c) The Alt Empordà (NE of Catalonia), bordering France and in which is located the other major producer and distributor of organic vegetables in Catalonia. 
In analyzing this category should compulsorily highlight other locations that nourish the Catalan capital. First, the Spanish geographic context, itself provides horticultural products to stores in Barcelona. In this case, the Andalusian provinces, mainly Almeria and Malaga, are notably harder. They are produced under plastic products consumed throughout the year in all of Spain, but right now they are out of season in outdoor cultivation. The paradigmatic product in this sense is the tomato. In this case, the productivist logic prevails in this trade that initially had been postproductivist [14] since in any of the types of establishment appeared this vegetable. In this sense, responsible for some of the smaller establishments argued that this type of product, even reluctantly, they had it in their offer because customers demanded it.

Secondly, one can not overlook the vegetables that come from outside the Spanish borders, they are also important in organic mode. Again, and greatly influenced by the proximity of some importers and distributors in the country, French products are the most numerous (lettuce, cabbage and turnips mainly). Also remarkable are the products arriving from Holland (carrots and onions). This section also has to consider the product that comes from outside Europe. In the Catalan market are products, such as green beans grown in North Africa, thus imitating the pattern of which is the offer at any time of the conventional trade and hallmark of industrialized agricultural production. These products are items out of season in the Catalan capital of Morocco preferably coming and they enter through the south of Spain where, after the analysis, they obtain official certification.

\subsection{The origin of dairy products}

In this case the origin was screened from 15 different milk products. Milk, cheese and yogurt made up the bulk of the search. Unlike the previous cases, the origin of dairy products is more widely distributed among the three scales of representation chosen for the presentation of this work (Fig. 3). The main difference is that in this category the products that come from Spain, Catalonia excluded from the analysis, are the most numerous. The reason lies in the fact that a Spanish province accounts for more than half of the data collected. This is Albacete province, which traditionally had a productive orientation linked to the use of sheep. In this province some years runs a successful company that makes dairy products of goat, sheep and cow. This business has successfully broken into the channels of commerce in most organic food stores, regardless of scale. Field tab was sought to know the origin of yogurt from cows, goats and sheep among twelve other products, and above all, the first two were mainly produced by that company. We also have to highlight another area of dairy production, Galicia. This is the main production area of organic cow's milk on the Spanish side, so it's not surprising that highlights prominently in shops in Barcelona, despite the thousand miles between the main processing plant UHT milk of the city of Barcelona.

Another singularity has been detected in the analysis of this category of products, is the high turnout with some European countries. Germany and France are the most repeated origins in the refrigerated shelves of organic dairy. In the 

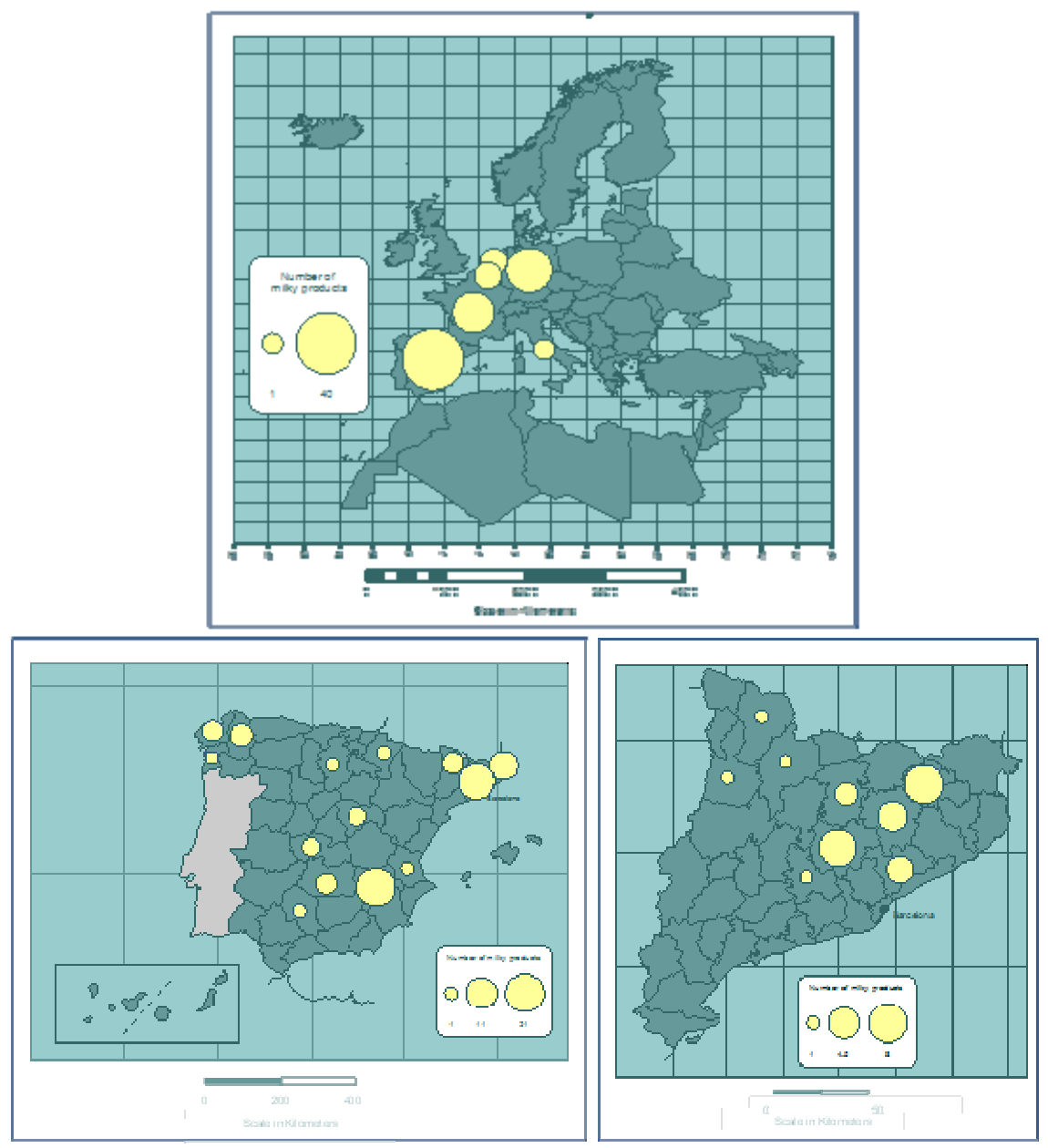

Figure 3: Geographical origin of organic milk products.

German case, several industrial operators are present in the milk processing dairy cow, although most highlights South regions (Bavaria). The French case is similar in terms of territorial specialization, most products found belong to a brand whose headquarters is located in French Brittany, but the variety of products is greater, not be confined only to animal products, but also introducing a line of soy milk, which is becoming more common in organic production.

Finally, it is necessary to mention that the milk produced in Catalonia also play an important role in shops that sell organic products. Of course, it tends to be located more frequently in smaller establishments, but also occur in so-called organic supermarkets. From the point of view of geographical distribution it must be said that is confined to the northern region of Catalonia (in the transition to the Pyrenees) and that its higher density development, they exist several 
different processors, is in regions where traditional cattle ranching had a certain importance for having natural conditions more suitable for animal feed (Garrotxa, Bages, Berguedà, etc.). The types of products that are produced in this area are presented often as local product in linear sales. As a consequence of this fact, consumers often valuate even higher their quality.

\section{Final remarks}

In the present study we have tried to begin the research about the origin of organic food consumed in the city of Barcelona. The main conclusions that have been reached are:

- The origins of the products are usually matched in most stores. The fact that many of the stores purchased through the same intermediaries minimizes the possibilities of differentiation in the origin of the products.

- The origins appeared more differentiated one the one hand in one of the most traditional stores in the organic sector, and on the other hand, in one of the most recent implementation stores. The socioeconomic characteristics of the two districts in which they are located are substantially different, although both receiving clients from other parts of the city and even outside of its municipal boundaries.

- There are no remarkable differences in the supply of organic products with regard to the specificity of the different socioeconomic districts studied. The most noticeable differences are focused on the ability of coverage and depth of assortment of different shops, depending much on the surface to be sold.

- For the consumer, it is sometimes difficult to identify the origin of the organic products they buy. The opinion of the majority of shopkeepers and business managers showed this is still an afterthought in the decision making process of buying and thus the specificity of origin sometimes is masked. By contrast, there is a small group of businesses that clearly indicates the geographical origin of the products studied.

- The organic horticultural products come mainly from Catalonia but other Spanish regions also have a notable presence. Dairy products show a better balance in terms of their geographical origin among the three scalar fields defined: Catalonia, Spain and Rest of World.

Consequently, the organic market in Barcelona today shows some typical characteristics of conventional food trade: a) the presence of off-season is remarkable; b) There are indications that there will be verified in future studies of mismatches between supply and demand of goods; c) it begins to have products that must travel thousands of miles to reach the shelves of the surveyed stores.

The information on the geographical origin is unequal and dispersed. Therefore seems necessary to move forward in the direction of providing more information to consumers that allows complete cycle product and geographical traceability in order to be more conscious and free in the choice of food products. 


\section{References}

[1] Ajuntament de Barcelona, Anuari Estadístic de la ciutat de Barcelona 2012. http://www.bcn.cat/estadistica/catala/dades/anuari/index.htm

[2] GFK, Estudio del perfil del consumidor de alimentos ecológicos. Ministerio de Medio Ambiente, medio Rural y Marino. 2011 http://www.magrama.gob.es/es/alimentacion/publicaciones/informe_consu midor_ecol\%C3\%B3gico_completo_(con_nipo)_tcm7-183161.pdf

[3] MAGRAMA, Agricultura Ecológica. Estadísticas 2011. 2012, http://www.magrama.gob.es/es/alimentacion/temas/la-agricultura-ecologica /INFORME_NACIONAL_2011_190912_tcm7-220494.pdf

[4] MARM, Marketing y alimentos ecológicos. Manual de aplicación a la venta detallista. 2009.http://www.magrama.gob.es/es/alimentacion/temas/ la-agricultura-ecologica/marketing_tcm7-8096.pdf

[5] DARP, El Govern crea una acreditació específica per a la venda de proximitat de productes alimentaris. 2013, http://www.govern.cat /pres_gov/govern/ca/govern/consell-executiu/acords-govern/acordgovern3241.html (8/1/2013).

[6] European Commision, Agriculture, fishery and forestry statistics, 2012 http://epp.eurostat.ec.europa.eu/cache/ITY_OFFPUB/KS-FK-12-001/EN/ KS-FK-12-001-EN.PDF

[7] FiBL, Organic Agriculture Worldwide: Key results from the survey on Organic agriculture worldwide 2012 Part 1: Global data and survey background, 2012.http://www.organic-world.net/fileadmin/documents/ yearbook/2012/fibl-ifoam- survey-data-2010-global-data.pdf

[8] Hjelmar, U., Consumers' purchase of organic food products. A matter of convenience and reflexive practices. Appetite. 56. pp.336-344. 2011.

[9] Weatherell, Ch.; Tregear, A. and Allinson, J., In search of the concerned consumer: UK public perceptions of food, farming and buying local. Journal of Rural Studies. 19. pp. 233-244. 2003.

[10] Aprile, M. C.; Caputo, V. and Nayga, M., Consumers' valuation of food quality labels: the case of the European geographic indication and organic farming labels. International Journal of Consumer Studies, 36, pp. 158165. 2012.

[11] Falguera, V.; Aliguer, N. and Falguera, M., An integrated approach to current trends in food consumption: moving toward functional and organic products? Food Control. 26. pp. 274-281. 2012.

[12] TNS Demoscopia, Baròmetre de percepció i Consum dels Aliments Ecològics 2010. http://www20.gencat.cat/docs/DAR/AL_Alimentacio /AL01_PAE/08_Publicacions_material_referencia/Fitxers_estatics/Baromet re_Quantitatiu_\%202010.pdf

[13] Gracia, A. and de Magistris, T., The demand for organic foods in the South of Italy: A discrete choice model. Food Policy. 33. pp. 386-396. 2008.

[14] Armesto, X. A. Notas teóricas en cuanto al concepto de postproductivismo agrario, Investigaciones Geográficas, 36, pp. 137-156, 2005. 